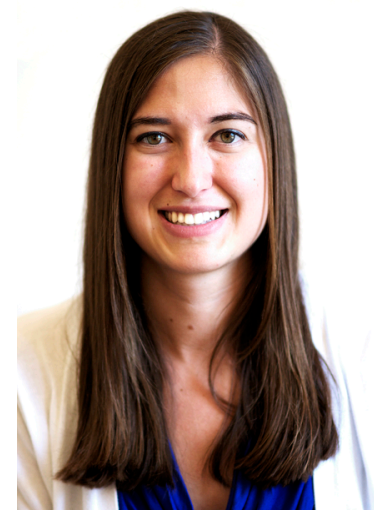

SAMANTHA HENNES is currently pursuing a Bachelor of Arts in History with a minor in Psychology, at Cal Poly, San Luis Obispo. While her passions in history vary, the movie industry has always had a particular draw for her, and she generally chooses to focus on social history. She is a member of the History Honor Society Phi Alpha Theta and is also involved on campus as an Ambassador for the Collage of Liberal Arts and a member of the first Greek letter fraternity for women Kappa Alpha Theta. 


\title{
FROM NOVELTY TO NEW ART: THE EVOLUTION OF THE INTELLECTUAL CRITICS' OPINION OF TALKIES
}

\author{
Samantha Hennes
}

Those involved in the movie industry during the late 1920s spoke constantly about talking pictures. Opinions on the "talkie" varied greatly, common headlines in both the Los Angeles Times and New York Times ranged from negative articles with headlines, such as "Beauty Lost in Talkies," "Talking Films Try Movie Men's Souls," and "Union's Discount 'Talkies" to more supportive articles, such as "All Films to Be Talkies," "Another Movie Miracle," and "Talking Picture New Era." While some viewed talkies as something to ridicule, calling them "moanies" or "squeakies," others viewed them as the future of the motion picture industry. ${ }^{2}$ The different opinions on talkies were not specific to certain member of the movie industry. Not all movie producers or directors liked talkies and not all critics or actors hated them. Monte Bell, a prominent film director of the time best explained the debate by using producers as an example. Bell

1 "Beauty Lost in Talkies," Los Angeles Times (December 16, 1928) c16., "All Films to Be Talkies," Los Angeles Times (March 8, 1928) A5, Chapin Hall, "Talking Films Try Movie Men's Souls," New York Times (June 8, 1928), 43. "Another Movie Miracle," New York Times (April 3, 1927) X7, Earle E Crowe, “Talking Picture New Era," Los Angeles Times (April 24, 1928) 12.

${ }^{2}$ Harry M, Geduld, "Appendix A" in The Birth of Talkies From Edison to Jolson (Bloomington: Indiana University Press, 1975), 269-274. 
had three producers who each gave the public different opinions on the talkie. While one producer claimed that silent film was dead, his counterpart would claim that silent film still had merit while another claimed that the talkie would revolutionize the industry. ${ }^{3}$ In examining the talkie debate, it becomes clear that opinions about the talkie were dynamic. As the silent film era came to a close many who spoke harshly of the talkie during its infancy came to support it. In general, movie directors and the public favored the talkie. ${ }^{4}$ One of the strongest voices in the early years against the talkie, however, was that of the intellectual film critic who represented a "higher-brow" movie-going audience that considered film to be art rather than just an entertainment. In order to better understand why this change of opinion in the talkie debate occurred I plan to examine the changing views of the intellectual critic during the silentto-sound transition era.

Thus far, scholars who mention the opinions of members involved in the talkie debate, only mention the opinions rather than analyze them, however the work of Myron Osborn Lounsbury examines the film critic and serves as a starting point for my analysis of the intellectual critic during the talkie era. ${ }^{5}$ While the primary focus of Lounsbury's book The Origin of American Film Criticism is the shift in vocabulary during the thirty-year period between 19091939, she does focus on an influential movement in film criticism that occurred during the talkie era, called the "little cinema movement". The "little cinema movement" had three goals: to exhibit foreign films that were unpopular to the masses but deemed important by intellectuals, to re-examine older but controversial movies, and to develop an audience for independent and experimental film makers. ${ }^{6}$ According to Lounsbury this movement influenced the quality of

\footnotetext{
${ }^{3}$ Monta Bell, "Movies and Talkies," The North American Review 226, no. 4, (October 1928): 430.

${ }^{4}$ Kenneth MacGowan, "When the Talkies Came to Hollywood," The Quarterly of Film Radio and Television 10, no.3, (Spring 1956), 294.

${ }^{5}$ These works include: Scott Eyman, The Speed of Sound Hollywood and the Talkie Revolution1926-1930 (New York: Simon \&Schuster, 1997); Andrew Sarris, "You Ain't Heard Nothin' Yet" The American Talking Film History and Memory 1927-1949 (New York: Oxford University Press, 1998); Donald Crafton, The Talkies: American Cinema's Transition To Sound 1926-1931 (New York: Macmillan Library Reference USA, 1997); E.S. Gregg, The Shadow of Sound (New York: Vantage Press, 1968); Harry M. Geduld, The Birth of The Talkies From Edison to Jolson (London: Indiana University Press, 1975).

${ }^{6}$ Myron Osborn Lounsbury, The Origins of American Film Criticism 1909-1939 (New York: Arno Press, 1973), 152.
} 
motion picture writing. Essentially what Lounsbury's examination of the "little cinema movement" suggests is that to some film, moved more towards the way of a serious art, rather than merely a source of entertainment. This notion of film as a serious art was a rather new concept during this time, however, it helps to explain why the intellectual critic was so harsh to the talkie. The intellectual critic, influenced by the "little cinema movement", held film to strict aesthetic standards and the talkie challenged their notion of these standards.

The intellectual critic of the talkie era explored the possibilities of film through their critiques of movies, and what they praised or neglected gave a great deal of insight into their opinions. In examining opinions and reviews of early and late talkies, it appears that the intellectual critic became more accepting of the talkie as they changed how they evaluated film. Before the talkie, the intellectual critic viewed film as a purely visual art; therefore they placed great importance on the visual aspects of a film, like the camera angles rather than the quality of dialogue. However, the talkie caused the intellectual critic distress because the use of sound and dialogue transformed what was once purely visual into a hybridization of forms, which confused their evaluation process. To reconcile this distress, the intellectual critic showed disdain for the talkies and dismissed it as a novelty. However, when it became clear that the talkie was not a fad, the intellectual critic readjusted, first, they stopped viewing film as a purely visual art and focused more on the actor on screen and then they moved toward improving the talkie in order to make it into a new form of art, that emphasized a harmony between visual aspects of film and dialogue.

\section{Intellectual Superiority: What Differentiated the Intellectual Critic from the Average Critic?}

The intellectual critic represented a movie-going population with sophisticated taste who expected more from the movies then than the masses. ${ }^{7}$ They viewed film as a source of art rather than just a source of entertainment. Unlike the studios the amount of money a movie made in the box office had little merit when it came to the evaluation of a film. To the intellectual critic, a film was enjoyable if it had artistic merit. Due to this emphasis on artistic merit

${ }^{7}$ Benjamin B. Hampton, History of the American Film Industry from its beginnings to 1931 (1931; repr, Dover Publications, 1970), 375. 
the intellectual critic represented a higher-minded audience that separated themselves from other critics by asserting their intellectual superiority. The intellectual critic achieved this by distancing themselves from the consumer aspects of film and the opinions of the masses.

The intellectual critic viewed the talkie as a gimmick to make money rather than a quality movie, so they used their intellectual superiority as a means to defend the artistic merit of film. One of the loudest voices in the attack of the talkie was artistic critic Gilbert Seldes. Seldes was a seasoned critic of the arts and wrote The 7 Lively Arts which examined various forms of art such as theater, music and dance. ${ }^{8}$ When it came to film evaluation, Seldes was more concerned with what he considered the "theoretical" approach in examining film, such as aesthetics, and was against what he considered the "practical" approach often taken by the movie industry that relied more on making money. ${ }^{9}$ Seldes attacked those involved in the practical side of the talkie debate; arguing that, "the director preoccupied with practical matters of the dull-witted and ignorant owner of movie property" did not handle movies for a "high-brow" audience well. ${ }^{10}$ Seldes' attack is a perfect example of how important it was for the intellectual critic to distance themselves from the consumer aspect of the movies. The fact that Seldes, uses words like "dull-witted" or "ignorant" indeed of words like "greedy" show that Seldes is more concerned with the intellectual aspect of a movie rather than its success or monetary value. He choice of words that attack the intelligence of movie makers, make the comparison that while these talkie makers are "ignorant" Seldes himself is intelligent for noticing these problems. Intelligence asserted the notion that film critics like Seldes understood the difference between good and bad cinema as opposed to the amount of money a production made.

Echoing back to ideals of "the little cinema movement" intellectual critics also asserted their intellectual superiority by reviewing unpopular movies they valued for artist merit as opposed to popular movies valued by the masses that were merely entertainment. Welford Beaton was an intellectual critic who voiced his praise for unpopular films as a way to differentiate himself from the masses.

${ }^{8}$ Gilbert Seldes, The Seven Lively Arts, (New York: Sagamore Press, 1924)

9 Seldes, An Hour With the Movies and the Talkies, (Philadelphia: J.B Lippincott Company, 1929) 96.

${ }^{10}$ Ibid., 96. 
Beaton owned The Film Specter which was a Hollywood periodical known for providing "a refreshingly unbiased Hollywood insider's view of the movies." Beaton he reviewed countless movies in this publication many of which were praised by Seldes. ${ }^{11}$ Beaton's review of the movie The Crowd exemplified the ideas of the intellectual critic as opposed to that of the masses. The Crowd was a silent film that came out during the talkie era and was considered widely unpopular. According to Beaton the film would not do well in the box office but he considered the film worthy of great deal of praise. ${ }^{12}$ The box office was a way for theater owners to hear the voice of the masses. When critics like Beaton went against the idea of the masses they suggested that film was something more than a product to them and that their ideas about film as an art were more thoughtful than those of the average film-going masses.

\section{A Visual Art: The Intellectual Critic's View of Film before the Talkie}

When the intellectual critic evaluated film, prior to the talkie era, one of the main things they focused on was the visual aspects of the films. The word choice in reviews of silent films suggests a great appreciation for the visual components of film. To the intellectual critic the camera was a key component in the process of making good films. The talkie challenged the idea of visual aspects of film being most important, and this explains the intellectual critics' initial resistance to the talkie.

When intellectual critics evaluated film they praised visual aspects of film because to them sound and dialogue were an unnecessary component of a good film. Gilbert Seldes' book An Hour With the Movies and the Talkies is a prime example of the amount of importance the intellectual critic placed on the visual aspects of films and emphasizes the importance of movement in silent films. He looked at the physical action of moving and talked about pantomime artists such as Charlie Chaplin. He notes Chaplin's facial expressions during a scene in The Gold Rush where Chaplin starts to dance the ballet, and Seldes explains how "you can see what is going on in his mind and what awaits him at the dinner party." ${ }^{13}$ To Seldes the facial expression was enough to tell a story and therefore it is easy to see how sound essentially is unnecessary to an art that

\footnotetext{
${ }^{11}$ Ibid., 94.

${ }^{12}$ Welford Beaton, "The Crowd," in Selected Film Criticism 1921-1930, ed. Anthony Slide (New Jersey: The Scarecrow Press Inc, 1982), 73.

${ }^{13}$ Seldes, An Hour With the Movies and the Talkies, 63-66.
} 
needs only visuals. Seldes rarely mentioned the plot or story of a film and his neglect of other aspects of film solidified the importance of the visual aspects to the intellectual critic. The language he used to describe films such as The Last Laugh suggested that a strong visual element made a film into art. He stated that, "It was as solid as a Dutch painting; as a movie it was interesting because everything that could be touched or heard or felt was somehow translated into visual terms." ${ }^{14}$ His comparison suggests that films were strengthened when their visual components fit together well. ${ }^{15}$ In fact, the intellectual critics during this era were so focused on visual aspects of film that to many, sound seemed unnecessary. The intellectual critic believed that art thrived when it worked within the limitations of its medium. ${ }^{16}$ For the intellectual critic this medium was purely visual and adding sound would change the medium, and the art.

The intellectual critic's notion of film being a visual art was challenged by the introduction of the talkie because it restricted the camera's freedom of movement. Before the introduction of the talkie the motion picture camera was thought to be not only the basis of the motion picture industry, but also highly perfected and readily portable. ${ }^{17}$ Many foreign silent film directors experimented with revolutionary camera angles. One example, the Russian cinema, mentioned in Seldes' book, featured increased camera movement and sweeping long shots. ${ }^{18}$ Consequently, the release of the talkie put a halt to much of this experimentation. Sound microphones restricted the movement of actors as well as the camera. Director Clarence Badger pointed out the flaw with the use of the camera when filming a talkie, "The difference is that the same lighting is serving both medium shot and close-up, so that one or the other is bound to lose something of its photographic beauty." ${ }^{19}$ The loss of photographic beauty would have been devastating to the intellectual critic since the visual aesthetics of film were of such great importance to them. The talkie changed the way that films were made; it demanded close-ups and soundproof stages which limited

${ }^{14}$ Ibid, 105.

15 The significance of Seldes' use of a Dutch painting is that from an art history standpoint, Dutch paintings are well known for their vibrant color and use of depth. While color was not an issue during this time period, the visual depth and life of a movie was.

${ }^{16}$ Ernest Lindergren, The Art of Film, (New York: The MacMillian Company 1963), 163.

${ }^{17}$ Austin C. Lescarboura, Behind The Motion Picture Screen,(1919 repr, New York: Benjamin Blom, 1971), 63.

${ }^{18}$ Seldes, An Hour With the Movies and the Talkies, 133-136.

19 "Beauty Lost in Talkies," Los Angeles Times (December 16, 1928) c16. 
the camera movements and the overall aesthetic style of the silent film praised so highly by the intellectual critic.

\section{Early Views on the Talkie: The Intellectual Critics Uncertainty in Evaluating the Talkie}

The talkie changed the way that films were made and how they looked. This caused a tension in the reviews of critics who did not know how to handle the shift. In the reviews of early talkies, there was a tension between the old style of film review, i.e. visual aspects, and the new review, which would appeal to the masses. At first, the intellectual critic was still too focused on comparing the talkie to silent films and this approach lead to a general dislike of talkies.

Talkies confused early intellectual reviewers because visual aspects were not longer the only way to tell a story, and while focusing on visual aspects alone was enough to evaluate a silent film, this was not a comprehensive enough evaluation for the talkie. Welford Beaton's review of the early talkie The Jazz Singer revealed the early tension film critics felt because of the talkie. In his review Beaton quickly criticized the overuse of the close-up. ${ }^{20}$ Seeing as the intellectual critic of the day was so focused on the camera and the visual aspects of film, the overuse of a close-up went against everything the intellectual critic found valuable in film. The problem with Beaton's review however, was that unlike the silent film, the talkie was not a purely visual art. Essentially the talkie was not purely visual because the addition of sound added a new aspect to the film. Dialogue replaced the sole reliance of facial expressions and movement to tell a story and this confused early talkie reviewers. Beaton seems aware of this dilemma and he acknowledges the fact that the talkie is a new kind of film. ${ }^{21}$ In his review he suggested that he would be unable to use typical motion picture standards to criticize this film. Although Beaton understood that the talkie was something new, because of this newness Beaton was ill equipped to evaluate the film.

Beaton was against sound in early talkie pictures because, like many other intellectual critics, he felt that sound was unnecessary, however Beaton was one of the first intellectual critics to realize that the talkie would dominate the movie industry. To Beaton, sound was unnecessary because, "Nothing that can

\footnotetext{
${ }^{20}$ Beaton, “The Jazz Singer," in Selected Film Criticism 1921-1930, 149.

${ }^{21}$ Ibid., 149.
} 
be left to the imagination should be included in a motion picture."22 Beaton thought the sight of a closing door was enough to allow the audience the chance to imagine the sound. The audience gave life to a silent picture, but with the talkie, the movie did that itself. ${ }^{23}$ So when Beaton reviewed the first talkie, The Jazz Singer, it seemed only natural that he would be against the use of sound. Although he was against sound, he also suggested that movie producers support the talkie because it would be foolish for them not to. According to Beaton, "As speaking pictures become better known the public will demand them." ${ }^{4}$ Beaton's mention of the public pointed out that the talkie was intended to please the masses, not the intellectual class of movie patron, but he also realized that ultimately the masses controlled the movie industry, and understood the inevitably of the talkie replacing silent films.

While Beaton understood that the talkie was inevitable, many other intellectual critics were not as certain; most of them did not evaluate the artistic aspects of the talkie because they considered it a passing fad. It was clear that the talkie was not something they took seriously. Richard Watts Jr's who wrote for The Film Mercury reviewed the talkie, The Broadway Melody and used the word "heart-warming" to describe it. When Watts uses the word "heartwarming" he is describing the emotion of the piece rather than evaluating the technical aspects of the film that make one feel this emotion, in doing this he focuses on the entertainment value of the piece rather than the intellectual or artistic value of the piece. In another review, Welford Beaton said the talkie The Cocoanuts did what it set out to achieve as it made the audience laugh. ${ }^{25}$ While both Watts and Beaton's reviews are positive about the talkies, they lack the critical scrutiny used in their evaluations of silent films suggesting the talkie was insignificant. After all, the role of a critic is to "ask and answer valuable questions about a work of art" and since critics failed to do this with certain talkies, it was clear they did not consider the talkie a work of art. ${ }^{26}$

\footnotetext{
${ }^{22}$ Beaton, Know Your Movies, (Hollywood: Howard Hill 1932), 98.

${ }^{23}$ Beaton, "Background for Screen Appreciation," The English Journal, no.2 (February 1941), 89.

${ }^{24}$ Ibid. 149.

${ }^{25}$ Richard Watts, "The Broadway Melody," in Selected Film Criticism 1921-1930,; Welford Beaton, "The Cocoanuts," in Selected Film Criticism 1921-1930, 63.

${ }^{26}$ Ernest Lindergren, The Art of Film, (New York: The MacMillian Company 1963), 163.
} 


\section{The Talkie is Here to Stay: How the Intellectual Critic Came to Accept the Talking Picture}

It was clear that the intellectual critic felt a great deal of dissonance when it came to the talkie. Alexander Bakshy, a critic similar to Seldes because of his background as an art critic, remarked, "It is a sad reflection of the limitations of intellectuals and artists all over the world to see history repeat itself in the contemptuous resentment with which they are greeting the talkie." ${ }^{27}$ While Bakshy appeared to argue against his fellow critic, in the same essay he critiqued the talkie. Bakshy's statement displays two separate needs: a shift in focus for the intellectual critic and improvements for the talkie. In order to accept the talkie, the intellectual critic needed to focus less on visual aspects of film and more on the presence of the character and also suggest ways in which the talkie could improve.

Richard Watts Jr. represented a major shift in how the intellectual critic viewed the talkie because of his focus on personal aspects of films. One of the first people Watts praised, James Gleason, was the writer of the talkie The Broadway Melody. In Watts' review, he highlighted the fact that the writer role gained significance as an important aspect of film. He praised Gleason in his review and said, "Nevertheless there was manifest with pleasant frequency throughout the picture a quality of dialogue and characterization..."28 As the talkie grew in public popularity many Broadway playwrights and journalists were involved in the scripts of movies because they understood how to write dialogue. Watts placed a great deal of importance on people involved in the movie, i.e. actors, writers, directors, etc. suggesting that because of a greater focus on people the intellectual critic was less focused on the visual aspects of film as the talkie grew in popularity.

The intellectual critics' shift in emphasis from a visual to personal aspects is best explained by the work of scholar Robert Spandoni whose research on the audiences' reception of early sound films suggests a growing importance of the "figure" or actor in sound films. While Spandoni's article focuses on audiences in general, his concept can still be applied to that of the intellectual critic because they were ultimately still members of the movie going audience.

\footnotetext{
${ }^{27}$ Alexander Bakshy, "The "Talkies" in American Movie Critics An Anthology From the Silents Until Now, ed. Phillip Lopate (New York: The Library of America 2006), 47.

${ }^{28}$ Watts, “The Broadway Melody," in Selected Film Criticism 1921-1930, 51.
} 
Spandoni argues that the figure on screen in sound films struck viewers as very present. ${ }^{29}$ It is obvious that the presence of these figures was noticed by the intellectual critic as evident in reviews from critics like Watts. As sound film became more and more popular the figure on screen became more important to the intellectual film critic. While Spandoni's work focuses on the beginning of the talkie era as well as the general publics' opinion, his work is still applicable to the intellectual critic in later years because their reception of the talkie was similar to that of the general public.

As the intellectual critic began to accept the talkie, it became clear that they wanted to evaluate the talkie as a new art, and therefore not compare the talkie to existing forms such as the silent film or theater. Before I go into the commentary these critics had on the talking picture I would first like to emphasize the word "new" when it came to the art to the talkie. Apart from silent films, the talkie was commonly compared to the stage. The intellectual critic of later talkies felt that the talkie was something different than both silent films and the stage which meant it would need to develop artist merit differently than existing forms. In fact, Gilbert Seldes was adamant that the talkies not borrow too heavily from the stage. Seldes thought that if the talkie borrowed from the stage it would hinder the medium's ability to grow. ${ }^{30}$ Similarly, Bakshy pointed out the flaw in comparing the talkie to the stage stating that the comparison implied that they dealt with the same material when in actuality they did not. ${ }^{31}$ To the intellectual critic of the late talkie it was clear that in order for the talkie to develop into something worthy of their time, improvements needed to be made; to make the talkie into a new art that was independent of the silent screen and the stage.

The intellectual critics felt the way the talkie handled dialogue did not meet the artistic standards they wished this new art to hold, and therefore because they were willing to critique it shows their acceptance of the talkie as more than just a fad. Seldes explained that one major flaw with motion picture dialogue was the strong reliance on it. He gave an example in his book An Hour With the Movies and The Talkies using a parting of two lovers. He explained that the

\footnotetext{
${ }^{29}$ Robert Spadoni, "The Uncanny Body of Sound," The Velvet Light Trap: A Critical Journal of Film and Television, no.51 (Spring 2003), 4.

${ }^{30}$ Seldes, An Hour With The Movies and the Talkies, 152.

${ }^{31}$ Bakshy, "The 'Talkies" in American Movie Critics, 47.
} 
two lovers in a talkie would merely say "we must part" as opposed to showing the emotion of the scene by saying the line and also showing an embarrassed young man and an angry young woman. ${ }^{32}$ Seldes was not alone in this opinion of the overuse of dialogue in the talkie. Another important intellectual critic of the era, Harry Potamkin, suggested that dialogue was the "anti-cinema" and thought that "speech-as-utterance" was a better route in use of natural speech. ${ }^{33}$ Overall, the intellectual critic wanted sound in films to be natural, not forced or unnecessary. However, the fact that these intellectual critics were paying attention to improving the talkie suggested that it was important to them. While they may not have accepted the talkie as art in the same respect as the silent screen, it became clear that the intellectual critic considered that, with some improvements, the talkie could be a new art.

As the intellectual critic accepted the talkie, their critical attitude and their reception coincided with that of the public. Famous scholar Walter Benjamin suggested that with most forms of visual and emotional enjoyment there would be a distinction between criticism and enjoyment. However, when it came to the screen there was no distinction, instead criticism and enjoyment coincided. ${ }^{34}$ While I agree with Benjamin's theory, he suggested that this fusion of criticism and enjoyment happened instantaneously. This was the case for the general public. However when applied to the intellectual critic it becomes clear that the fusion of criticism and enjoyment happened gradually over time. The intellectual critic of the late 1920s and the 1930s was a complex individual. Struggling to separate themselves from the masses and representing a different set of the movie-going population, the intellectual critics' acceptance of the talkie did not happen at the same time as the general public.

Once they looked at the talkie in a different light many of these intellectual critics became more accepting of the talkie as a new art, rather than something to be compared to silent films. To the intellectual critic, film was a purely visual art that they held to strict aesthetic standards. With the introduction of the talkie the visual performance of these films did not meet the standards of the intellectual critic. This caused a great deal of disagreement amongst critics.

\footnotetext{
32 Seldes, An Hour With The Movies and the Talkies, 142.

${ }^{33}$ Harry Alan Potamkin, "'A' in the Art of the Movie and Kino," in American Movie Critics, 48.

${ }^{34}$ Walter Benjamin, Illuminations, ed. Harry Zohn, 1968 reprint, (New York: Schocken Books, 2007).
} 
While in the early years many intellectual critics viewed the talkie as something for the masses, once it became clear that the talkie had staying power, the intellectual critic found a new way to evaluate film. Rather than focusing on visual aspects alone, they focused on the personal aspects of film. They also realized that the talkie needed to be improved before they could completely accept the new art. The talkie presented the intellectual critic with a way to re-evaluate what elements were important to the art of film, and while the talkie was still very much in infancy during this time their critiques showed that they believed, with some improvement, the talkie could reach a new level of artistic merit. 
Bakshy, Alexander. "The 'Talkies" in American Movie Critics An Anthology From the Silents Until Now, ed. Phillip Lopate. New York: The Library of America 2006.

Beaton, Welford. "Background for Screen Appreciation," The English Journal, no.2 (February 1941): 89-100.

_. "The Cocoanuts," "The Crowd," and "The Jazz Singer," in Selected Film Criticism 1921-1930. Edited by Anthony Slide. New Jersey: The Scarecrow Press Inc, 1982. . Know Your Movies. Hollywood: Howard Hill 1932.

Bell, Monta. "Movies and Talkies," The North American Review 226 no. 4 (October 1928):429-435.

Benjamin, Walter Illuminations, Edited by Hannah Arendt, translated by Harry Zohn, 1968. Reprint, New York: Schocken Books, 2007.

Crafton, Donald. The Talkies: American Cinema's Transition To Sound 1926-1931. New York: Macmillan Library Reference USA, 1997.

Eyman ,Scott. The Speed of Sound Hollywood and the Talkie Revolution1926-1930. New York: Simon \&Schuster, 1997

Geduld, Harry M. "Appendix A" in The Birth of Talkies from Edison to Jolson. Bloomington: Indiana State University Press, 1975.

Gregg, E.S. The Shadow of Sound. New York: Vantage Press, 1968.

Hampton, Benjamin B. History of the American Film Industry from its beginnings to 1931. 1931. Reprint, Dover Publications, 1970.

Lescarboura, Austin C. Behind The Motion Picture Screen. 1919. Reprint, New York: Benjamin Blom, 1971.

Lindergren, Ernest. The Art of Film. New York: The MacMillian Company 1963.

Lounsbury, Myron Osborn. The Origins of American Film Criticism 1909-1939. New York: Arno Press, 1973. 
MacGowan, Kenneth. "When Movies Came to Hollywood," The Quarterly Film and Television Review 10, no.3 (Spring 1956): 288-301.

Potamkin, Harry Alan. "'A' in the Art of the Movie and Kino," in American Movie Critics.

Sarris, Andrew. "You Ain't Heard Nothin' Yet" The American Talking Film History and Memory 1927-1949. New York: Oxford University Press, 1998.

Seldes, Gilbert. An Hour With the Movies and the Talkies. Philadelphia: J.B Lippincott Company, 1929.

—. The Seven Lively Arts. New York: Sagamore Press, 1924.

Spadoni, Robert. "The Uncanny Body of Sound," The Velvet Light Trap: A Critical Journal of Film and Television, no.51 (Spring 2003).

Watts, Richard Jr. "The Broadway Melody," in Selected Film Criticism 1921-1930. Edited by Anthony Slide. New Jersey: The Scarecrow Press Inc, 1982. 